\title{
The effects of analgesic treatment and chest physiotherapy on the complications of the patients with rib fractures that arise from blunt chest trauma
}

\author{
Timuçin Alar, M.D., ${ }^{1}$ (1) İsmail Ertuğrul Gedik, M.D., ${ }^{2}$ (1) Murat Kara, M.D. ${ }^{3}$ \\ 1'Department of Thoracic Surgery, Çanakkale Onsekiz Mart University Faculty of Medicine, Çanakkale-Turkey \\ 2Department of Thoracic Surgery, Erzurum Regional Education and Research Hospital, Erzurum, Turkey \\ ${ }^{3}$ Department of Thoracic Surgery, İstanbul University İstanbul Faculty of Medicine, İstanbul-Turkey
}

\begin{abstract}
BACKGROUND: This prospective study aims to investigate the effect of chest physiotherapy and analgesic therapy on the possible complications of isolated rib fractures attributable to blunt thoracic trauma, such as hemothorax and pneumothorax.

METHODS: Patients who presented to Çanakkale Onsekiz Mart University School of Medicine Hospital's Emergency Department and Thoracic Surgery outpatient clinics within the first 24 hours of the post-traumatic period and did not have additional intrathoracic complications at presentation with blunt thoracic trauma and who were diagnosed with isolated rib fractures were enrolled in this prospective research study. The groups were designated as the patients who would receive analgesic treatment only (Group A) and the patients who would receive chest physiotherapy and analgesic treatment together (Group B). Patients who had first and second rib fractures or three or more rib fractures and who did not have additional organ injury were hospitalized in the Thoracic Surgery clinics; patients who had other organ trauma were hospitalized in related clinics. Patients were reassessed on their seventh and $30^{\text {th }}$ post-traumatic days with physical examination and radiologic studies.
\end{abstract}

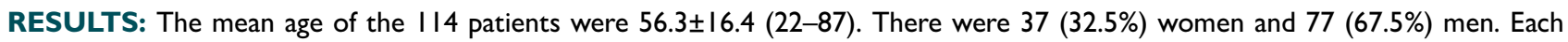
group included 57 patients. The most common form of trauma was the same-level falls $(31.6 \%)$. The mean number of rib fractures of all participants was $2.6 \pm 0.7(1-10)$; the median number was I.5. Fifty-two (45.6\%) patients were hospitalized. The mean length of stay was $4.0 \pm \mathrm{I}$. I days. At the end of their treatment and follow-up periods, pleural effusion was found in 28 patients (24.6\%) out of I I 4 enrolled at the side of trauma. Group B had a higher number of patients with pleural effusion (43.9\%) than group A (5.3\%). We performed tube thoracostomy in four patients, all of which were in group $B(p<0.05)$.

CONCLUSION: As a result of this study, chest physiotherapy maneuvers have increased the incidence of late hemothorax in patients with three or more isolated rib fractures. Also, minimal hemothoraces $(<300 \mathrm{ml})$ may spontaneously regress, and no additional surgical treatment are required if the proper follow-up procedures are performed. It is advisable to hospitalize the blunt thoracic trauma patients who have three or more rib fractures and who are planned to undergo chest physiotherapy and or are prone to develop additional complications because of possible risks.

Keywords: Blunt thoracic trauma; chest physiotherapy; hemothorax; rib fracture.

\section{INTRODUCTION}

Traumas are generally divided into two groups as blunt and penetrating traumas. Blunt traumas have higher morbidity and mortality rates because of additional organ and system injuries that accompany them. ${ }^{[1]}$

\footnotetext{
Cite this article as: Alar T, Gedik IE, Kara M. The Effects of analgesic treatment and chest physiotherapy on the complications of the patients with rib fractures that arise from blunt chest trauma. Ulus Travma Acil Cerrahi Derg 2020;26:531-537.

Address for correspondence: Timuçin Alar, M.D.

Çanakkale Onsekiz Mart Üniversitesi Tıp Fakültesi, Göğüs Cerrahisi Anabilim Dalı, Çanakkale, Turkey

Tel: +90286 - 2635950 E-mail: timucinalar@gmail.com

Ulus Travma Acil Cerrahi Derg 2020;26(4):53I-537 DOI: 10.14744/tjtes.2019.26356 Submitted: 24.02.2019 Accepted: 09.12.2019 Online: I5.06.2020

Copyright 2020 Turkish Association of Trauma and Emergency Surgery
} 
Rib fractures (RF) are the most common complication trauma patients as they occur in 10\% of the trauma patients. RF may cause pulmonary contusion hemopneumothorax and pulmonary laceration. ${ }^{[1]}$ Additionally, RF may hinder the respiration mechanism and cause secretion retention in the airways and thus cause serious complications, such as atelectasis and pneumonia attributable to the pain they cause. ${ }^{[2]}$ Unfortunately, there is not enough scientific information about chest physiotherapy (CP), which is performed to prevent such complications that may or may not cause hemopneumothorax. The effects of CP and analgesic treatment (AT) on the development of hemopneumothorax in patients with isolated rib fractures secondary to blunt thoracic trauma (TT) is researched in this prospective randomized study.

\section{MATERIALS AND METHODS}

This prospective research study was approved by the $\mathrm{Hu}-$ man Studies Ethical Committee of Çanakkale Onsekiz Mart University (Date: 13/02/20 I 3 Decision Number: 2013/05-04). Patients who were diagnosed with isolated RF secondary to blunt TT who presented to Çanakkale Onsekiz Mart University School of Medicine Hospital's Emergency Department and Thoracic Surgery outpatient clinics in the first 24 hours following the trauma between 03/0I/2013-03/01/2016 were enrolled. The diagnosis of RF was established with patients' medical history, physical examination (PE), posterior-anterior (PA) chest x-ray, and thoracic computerized tomography (CT). The informed consent of all patients was obtained who participated in this study. Patients who had additional intrathoracic injuries, such as hemothorax, pneumothorax, flail chest, atelectasis, pneumonia or requiring hospitalization to intensive care unit (ICU) at the time of hospital admission, were excluded from this study. Patients who had predisposing medical conditions for pneumothorax, such as bullous emphysema and predisposing medical treatment with antiaggregant or anti-coagulant drugs at the time of admission, were not enrolled. However, patients with additional extrathoracic organ injuries were enrolled.

Patients were divided into two groups using a shuffled deck of cards within a closed envelope. The groups were designated as the patients who will receive AT only (Group A) and the patients who will receive $\mathrm{CP}$ and AT together (Group B). $\mathrm{Pa}$ tients who were diagnosed with first and second RF and patients with three or more RF were hospitalized in the Thoracic Surgery Clinics. Patients who had additional extra-thoracic organ injuries were hospitalized in the respective clinics. The necessary treatments were arranged in the outpatient clinics to the patients who did not meet these criteria. All cases were evaluated twice in the Thoracic Surgery outpatient clinics at the end of the first week and the first month following their trauma with PE and radiological studies. A similar follow-up protocol was performed to the patients who were still hospitalized at the end of the first week after their trauma. The consort diagram of the study is given in Figure I.

\section{Analgesic Treatment}

Diclofenac sodium $(2 \times 75 \mathrm{mg} /$ day intramuscular $)$, acetaminophen $(2 \times 1000 \mathrm{mg} /$ day intravenous or $4 \times 500 \mathrm{mg}$ peroral) and thiocolchicoside ( $2 \times 4 \mathrm{mg} /$ day intramuscular) were administered to the patients who were hospitalized at the Thoracic Surgery or other clinics with the diagnosis of isolated rib fractures for seven days. Patients did not receive additional treatment during this period. Patients who were hospitalized were evaluated with daily PE and hemogram tests. PA chest $x$-rays were performed to the patients with diminished lung auscultation sounds and decreased hemoglobin levels. A decrease of $\mathrm{Igr} / \mathrm{dl}$ in hemoglobin is considered significant only if confirmed with the PE. Thoracic ultrasonography (USG) was performed to all patients with findings suggesting pleural effusion on PA x-rays. The presence and the amount of pleural effusions were determined with USG. We performed diagnostic thoracentesis to all patients who had pleural effusions on USG to investigate if the pleural effusion is of hemorrhagic origin. Patients who had pleural effusions with the volume higher than what was necessary enough to diminish the costo-phrenic sinus on PA x-ray (approximately $300 \mathrm{ml}$ ) underwent chest tube thoracostomy using a 32 French (Fr) chest tube. Cases with lesser amounts of pleural effusions were evaluated with daily $P E$, hemogram tests and PA x-rays. Chest tubes were removed from the patients when the daily drainage levels were below $200 \mathrm{ml}$.

Patients who were followed up on outpatient clinics were prescribed with diclofenac sodium ( $2 \times 75 \mathrm{mg} /$ day per-oral), acetaminophen (4x500 mg per-oral) and thiocolchicoside $(2 \times 4$ $\mathrm{mg} /$ day per-oral) for seven days. Acetaminophen $(4 \times 500 \mathrm{mg}$ per-oral) was prescribed for an additional seven days to the patients who still describe pain after this period. The patients who were hospitalized were prescribed the same drugs on their discharge. Patients were evaluated for the presence of complications at the outpatient clinical examinations with PE and PA chest $x$-ray at the end of their treatment. Identical procedures were performed to the patients who develop signs of pleural effusion.

\section{Chest Physiotherapy}

Patients who were in the chest physiotherapy group performed incentive spirometry in addition to the identical analgesic treatment with the other group. Incentive spirometry was performed with intentional coughs five times every hour and inspiration/expiration exercises five times every $30 \mathrm{~min}$ utes using the Triflow device. In addition to those maneuvers, patients were mobilized for 15 minutes every three hours when they were awake. Postural drainage and chest percussion maneuvers were not performed.

Patients who were treated at outpatient clinics were taught how to perform these maneuvers thoroughly and were asked to perform them during their first outpatient clinics examinations. Patients were also given checklists and asked to bring 


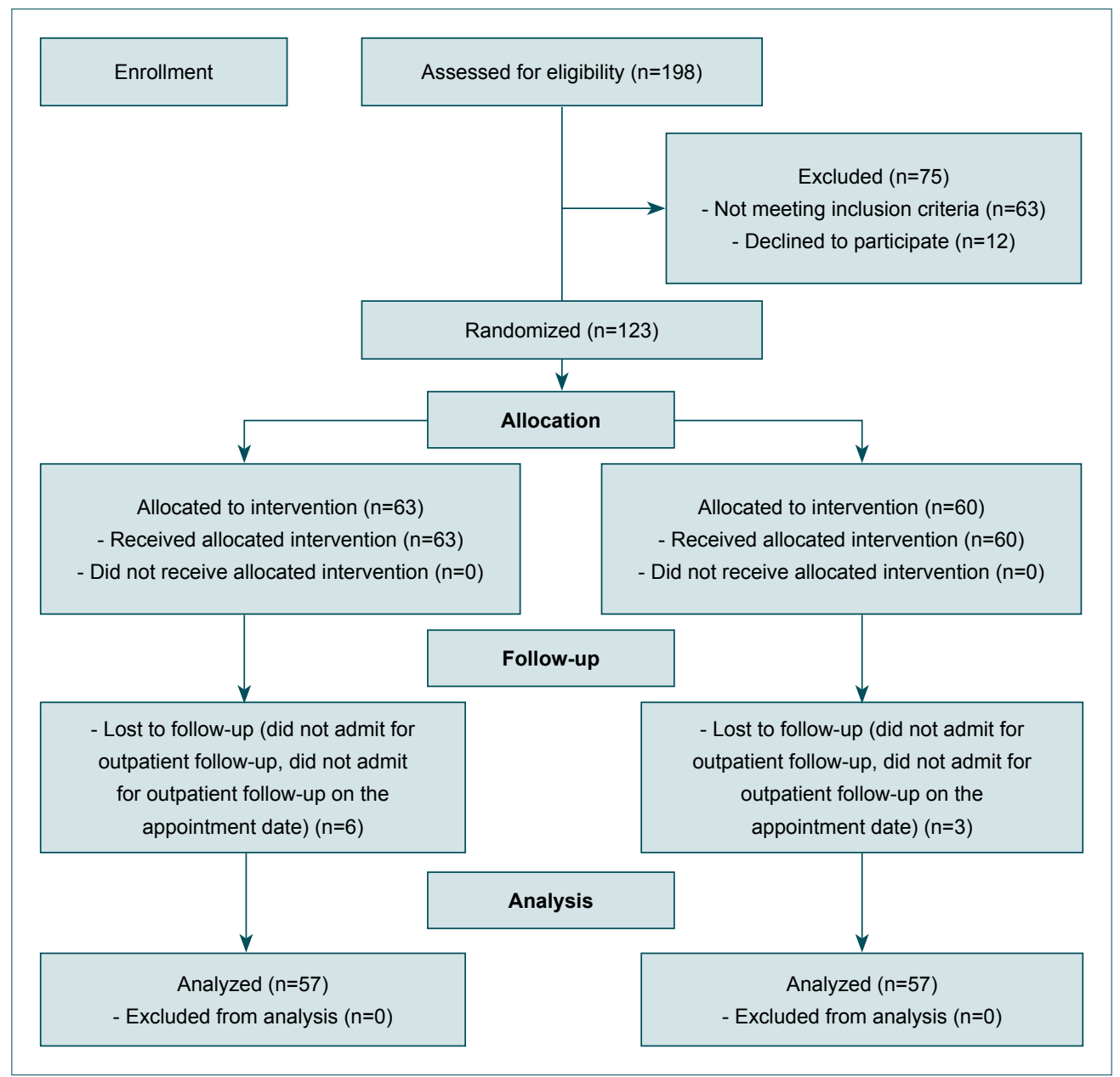

Figure 1. The consort diagram of this study.

them to their follow-up examinations to be certain that they performed chest physiotherapy maneuvers.

\section{Statistical Analysis}

G*Power (v3.I.9) software was used for power analysis to determine the sample size. A pilot research study was performed, including 20 patients in each group. Late-onset hemothorax ratio was found in one (5\%) patient in Group A and five (25\%) patients in Group B. The sample size was calculated using these results of the pilot study. According to the results of the pilot study, the effect size was found to be $w$ : 0.280 on the $\alpha=0.05$ and $\beta=0.20$ levels. The required sample size for this study was found to be $10 \mathrm{I}$ cases, and considering the data losses, this number was increased by $20 \%$. Thus, the final calculation was found as 121 .

Distribution and frequency of the data were analyzed after the data was transferred to digital media. Treatment and control groups were compared with each other for the demographic data. Descriptive values, such as mean, median, standard deviation, range, and percentage, were calculated. The difference between the means of numerical values was calculated using the Mann-Whitney $U$ test. Categorical data differences between the two groups were analyzed using the Pearson Chi-Square test. Fisher's exact test was used if a value in the Chi-Square test was less than 5. The explanatory power of the study model for the hypothesis was evaluated using Cox \& Snell R Square and Nagelkerke R Square Binominal Logistical Regression Analysis. The $\mathrm{P}$-value of less than 0.05 was considered to be statistically significant in all statistical tests.

All statistical analysis was carried out using the Statistical Package for Social Sciences (SPSS ${ }^{\circledR}$ ) version 19 software.

\section{RESULTS}

The mean age of the I I 4 participants were $56.3 \pm$ I $6.4(22-87)$ And 37 patients (32.5\%) were women and 77 (67.5\%) were men. The mean age of the women was $56.2 \pm 14.9$ (28-86), and the mean age of the men was 56.3 17.1 (22-87). The comparison of the mean ages of both groups was not statistically significant $(p>0.05)$.

Group A (Analgesic) B (Analgesic and Chest Physiotherapy) included 57 patients each. The mean age of Group $A$ was $54.2 \pm 16.1$ (22-86), Group B was 58.4 16.5 (22-87), and the difference between the two groups was not statistically sig- 
nificant $(p>0.05)$. Group A included 20 (35.1\%) women and $37(64.9 \%)$ men. Group B included 17 (29.8\%) women and $40(70.2 \%)$ men. The difference between the two groups was not statistically significant $(p>0.05)$.

Patients' trauma types were grouped as motor vehicle accidents, in which the victim was a car occupant (MVA), motor vehicle accidents in which the victim was a pedestrian (MVAP), motorbike accident (MA), fall from heights (FFH) and fall from the same level (FFS). The most common type of accident in our study was FFS. The types of trauma were compared between the two groups, and there was no statistically significant difference between them ( $p>0.05)$. The distribution of trauma types among the groups is detailed in Table I.

The mean number of RF of I I 4 patients enrolled in our study was 2.6 $\pm 0.7(1-10)$; the median number was I.5. The mean number of RF in both groups was calculated to be $2.2 \pm 1.5$ (I-7) for Group A and 3.0 2 2.0 (I-10) for group B. The median number of RF was two for Group $A$ and three for Group $B$. The difference between the mean RF between the two groups was statistically significant $(p<0.018)$.

In this study, 52 (45.6\%) out of I I4 patients were hospitalized. The distribution of the patients who were hospitalized and who were treated in outpatient clinics between the two groups is detailed in Table I. The difference of the patients who were hospitalized and who were not hospitalized between the two groups was not statistically significant $(p>0.05)$ (Table 2).

The mean hospital stay of the patients who were enrolled in our study was $4.0 \pm 1$.I days. The mean hospital stay of the patients in Group A was 3.6 \pm 0.8 days and $4.3 \pm 1.2$ days in Group B. The mean hospital stay of the patients in Group B was significantly longer than Group A $(p<0.003)$.

There were extra-thoracic injury in 18 (15.8\%) patients out

Table I. The distribution of the trauma types among the groups

\begin{tabular}{|c|c|c|c|}
\hline Trauma type & $\frac{\text { A }}{\text { n (\%) }}$ & $\frac{\text { B }}{\text { n (\%) }}$ & $\begin{array}{c}\text { Total } \\
\text { n (\%) }\end{array}$ \\
\hline $\begin{array}{l}\text { Motor vehicle accide } \\
\text { car occupant }\end{array}$ & $3(5.3)$ & $5(8.8)$ & $8(7.0)$ \\
\hline $\begin{array}{l}\text { Motor vehicle accide } \\
\text { pedestrian }\end{array}$ & $12(2||)$. & $14(24.6)$ & $26(22.8)$ \\
\hline Fall from same level & $22(38.5)$ & $14(24.6)$ & $36(31.6)$ \\
\hline Fall from heights & $14(24.6)$ & $19(33.2)$ & $33(28.9)$ \\
\hline Motorbike accidents & $6(10.5)$ & $5(8.8)$ & II (9.7) \\
\hline Total & $57(100)$ & $57(100)$ & $114(100)$ \\
\hline
\end{tabular}

*Column percentages were calculated. of II 4.7 (I2.9\%) patients were in Group A, and II (I9.3\%) of the patients were in Group B. Regarding extra-thoracic injuries there was no statistically significant difference between two groups ( $p>0.05)$. The most common type of extra-thoracic injury was the fracture of the transverse processes of the thoracic vertebrae.

At the end of the treatment and follow-up periods, there were $28(24.6 \%)$ out of 114 patients who were diagnosed with pleural effusion at the same side of RF. We performed thoracentesis to these 28 patients to establish the diagnosis of hemothorax. All of these 28 pleural effusions were hemothoraces. The distribution of patients who developed hemothorax between two groups was calculated, and Group $B$ was found to have significantly $(p<0.000 I)$ more patients with hemothorax than Group A (Table 3).

Table 2. The distribution of the patients who were hospitalized and who were treated in outpatient clinics between two groups

\begin{tabular}{|c|c|c|c|}
\hline \multirow[t]{2}{*}{ Treatment status } & A & B & Total \\
\hline & n (\%) ${ }^{*}$ & n (\%) ${ }^{*}$ & n (\%) ${ }^{*}$ \\
\hline Outpatient clinics & 34 (59.6) & $28(49.1)$ & $62(54.4)$ \\
\hline Hospitalized & $23(40.4)$ & $29(50.9)$ & $52(45.6)$ \\
\hline Total & $57(100)$ & $57(100)$ & II4 (100) \\
\hline
\end{tabular}

*Column percentages were calculated.

Table 3. The distribution of the patients who developed hemothorax between two groups

\begin{tabular}{|c|c|c|c|}
\hline \multirow[t]{2}{*}{ Result of follow-up } & A & B & Total \\
\hline & n (\%) ${ }^{*}$ & n (\%) & n (\%) ${ }^{*}$ \\
\hline No hemothorax & $54(94.7)$ & $32(56.1)$ & $86(75.4)$ \\
\hline Hemothorax & $3(5.3)$ & $25(43.9)$ & $28(24.6)$ \\
\hline Total & $57(100)$ & $57(100)$ & II4 (100) \\
\hline
\end{tabular}

*Column percentages were calculated.

Table 4. The distribution of the patients who were treated in outpatient clinics between two groups

\begin{tabular}{|c|c|c|c|}
\hline \multirow{2}{*}{$\begin{array}{l}\text { Patients treated in } \\
\text { outpatient clinics }\end{array}$} & \multirow{2}{*}{$\begin{array}{c}\text { A } \\
\mathbf{n}(\%)^{*}\end{array}$} & \multirow{2}{*}{$\begin{array}{c}\text { B } \\
\text { n (\%) }\end{array}$} & \multirow{2}{*}{$\begin{array}{c}\text { Total } \\
\mathbf{n}(\%)^{*}\end{array}$} \\
\hline & & & \\
\hline No hemothorax & $34(100)$ & 27 (96.4) & 61 (98.4) \\
\hline Hemothorax & $0(0)$ & I (3.6) & I (I.6) \\
\hline Total & $34(100)$ & $28(100)$ & $62(100)$ \\
\hline
\end{tabular}

*Column percentages were calculated. 
Only one (1.6\%) patient out of 62 patients who were treated in outpatient clinics developed hemothorax who was also in group B (Table 4). The patient recovered spontaneously without any intervention.

Chest tube thoracostomy was carried out in four (14.3\%) out of 28 patients who developed hemothorax. All patients who underwent tube thoracostomy were in Group B. When the difference concerning surgical intervention was compared between two groups, having all four tube thoracostomies were performed in Group B was statistically significant $(p<0.04 I)$. The 24 patients' whose tube thoracostomy was not performed had hemothorax just enough to consolidate the costo-phrenic sinus $(<300 \mathrm{ml})$. Changes in the hemothorax amount were inspected using PE, PA x-rays, or thoracic USG daily during the hospital stay and at the 7th and 30th days after discharge. Hemothoraces of all these patients regressed spontaneously, and no additional surgical intervention was required at the end of the 30 days follow-up.

The patients enrolled in our study were regrouped as the patients who had three or more RF and the ones with less than three. There were 67 (58.8\%) patients with less than three RF, and 47 (4I.2\%) had more than three RF. When we compared our original groups regarding the number of RF, Group A had 34 patients with RF less than three and 23 patients with three or more. Group B had 28 patients with less than three RF and 29 with three or more RF. There was no statistically significant difference between the two groups $(p>0.05)$. Two groups were compared for the development of complications. No patients developed hemothorax in patients with less than three RF. In contrast, all patients who developed hemothorax had three or more RF.

The mean hospital stay of the four patients who undergone chest tube thoracostomy out of 52 who were hospitalized was $6.5 \pm \mathrm{I} .3$ days, and 48 patients who did not require surgical intervention were $3.8 \pm 0.8$ days. The difference between the mean duration of hospital stay was statistically significant $(p<0.000 \mathrm{I})$.

None of the 114 patients developed complications, such as pneumothorax, atelectasis, or pneumonia, retained hemothorax, empyema, and there was no mortality. The power of our study to explain the hypothesis was analyzed with binominal logistical regression analysis. The results of this analysis were $54.3 \%$ in Cox \& Snell R Square and $80.9 \%$ in Nagelkerke R Square.

\section{DISCUSSION}

Trauma is still an important etiology of morbidity and mortality. It has been reported as the most common cause of death between ages $1-44$. Blunt TT is the direct cause of death in $25 \%$ of the trauma patients and is an additional etiological factor in another $50 \%$ of deaths that arises from trauma.
Thus, TT is present in $75 \%$ of the patients who succumbed to trauma. ${ }^{[3]}$

The most common cause of all TT and blunt TT is MVA. A study from Turkey identified that MVA is the cause of TT in $63 \%$, and falls are the cause of $25 \% .{ }^{[4]}$ In international studies, MVA constitutes $43.7 \%-45 \%$, and falls constitute $20 \%$ of the TT, which are less than Turkey's data. ${ }^{[5,6]}$ In our study, the most common cause of blunt TT has been found to be falls passing MVA. We believe that this situation is caused attributable to the presence of agricultural and livestock farming facilities in our hospital's region.

The mean age of the II4 participants in our study were $56.3 \pm 16.4$ (22-87). This is higher compared to similar studies about blunt thoracic trauma. ${ }^{[7]}$ We believe this result occurred because the hospital that this study was conducted is in the city of Çanakkale, which has the second oldest median age (36.7) in Turkey. ${ }^{[8]}$

In our study, I8 (15.8\%) cases had extra-thoracic injuries. The most common type of extra-thoracic injury was the fracture of the transverse processes of thoracic vertebrae, which is compatible with other studies. ${ }^{[5]}$

None of our patients developed complications, such as pneumothorax, atelectasis, or pneumonia, retained hemothorax, empyema, and there was no mortality. The incidence of atelectasis in blunt TT is reported between $1.7 \%-10.2 \% .^{[7,9]} \mathrm{We}$ think that the reason our patients did not develop atelectasis is proper pain management, and the patients who were enrolled have isolated RF.

It was reported that $25 \%$ of patients who had multiple RF develop pneumothorax, and $81 \%$ of the patients who had two or more RF develop hemothorax. ${ }^{[10]}$ Traumatic hemo-pneumothoraces usually occur in the acute post-traumatic period, but they may also occur in a chronic setting. ${ }^{[10]}$ Hemothorax is reported to develop more often than pneumothorax in chronic post-traumatic period. ${ }^{[11,12]}$ When the patients enrolled in our study were regrouped as the patients who had three or more RF and the patients with less than three RF, delayed hemothorax developed only in the former group. At the end of the treatment and follow-up periods, there were $28(24.6 \%)$ out of II 4 patients who were diagnosed with hemothorax at the same side of RF. Three of the 28 patients were in Group A and 25 patients were in Group B. The incidence of delayed hemothorax in Group A in which the patients received analgesic treatment only was $5.3 \%$, but it was $43.5 \%$ in Group B in which patients received both analgesic treatment and chest physiotherapy together. In contrast to similar studies in which the incidence of delayed hemothorax is around $5 \%$, this $43.5 \%$ ratio is exceptionally high. ${ }^{[2]}$ We believe that the difference in the incidence of delayed hemothorax arises from chest physiotherapy performed in Group B. It is suggested that all traumatic hemothoraces should be 
drained with chest tube thoracostomy regardless of their volume, ${ }^{[13]}$ but several studies suggest that hemothoraces with the volume less than $300 \mathrm{ml}$ can be observed without performing chest tube thoracostomy if the patient's general status is good. ${ }^{[14]}$ The patients who developed hemothorax but did not undergo chest tube thoracostomy had pleural effusion just enough to consolidate the costo-phrenic sinus $(<300 \mathrm{ml})$. The hemothoraces in all these patients spontaneously regressed without the need for surgical intervention. The hemothoraces less than $300 \mathrm{ml}$ can be observed without the need of surgical intervention was also found as an additional conclusion.

In patients with blunt TT, chest physiotherapy is reported to have favorable effects on late-term complications, such as atelectasis and pneumonia. ${ }^{[15]} \mathrm{It}$ is also reported that postural drainage should not be performed, and percussion maneuvers should be carefully performed in patients with RF. ${ }^{[16]}$ We did not perform these maneuvers to our patients. The powerful inspiration and coughing maneuvers cause a sudden expansion in chest volume and change the ICS distances in patients with RF. This situation may cause the bone fragments of the fractured ribs to move and cause tension and rupture of the underlying intercostal vessels. This may also cause lung parenchymal injury and complications, such as delayed hemopneumothorax, especially in patients with displaced RF. Chest physiotherapy is found to increase the incidence of delayed hemothorax in patients with RF secondary to blunt TT in our study, which is also found to be statistically significant. Because of this, we believe that chest physiotherapy should be carefully performed in patients with additional injuries and diseases, such as lung contusion and COPD in which additional complications, such as atelectasis and pneumonia may quickly develop. To prevent such complications, we believe that patients who have three or more RF should be closely monitored and treated in hospital.

The limitations of this study are that this study involves both patients treated in outpatient clinics and the patients who were hospitalized, which may cause a heterogenous distribution among cases and that there are not many studies that encompass the adverse effects of chest physiotherapy on blunt thoracic trauma that could support our findings.

\section{Conclusion}

As a conclusion of this prospective research study in which the effects of chest physiotherapy on the complications in patients with isolated RF secondary to blunt TT, chest physiotherapy increased the incidence of delayed hemothorax in patients who had three or more RF. There was no effect of chest physiotherapy on the development of delayed hemothorax in patients with less than three RF. In addition to these minimal amounts of hemothorax ( $<300 \mathrm{ml})$ spontaneously regressed if the proper follow-up procedures are implemented. Delayed hemothorax secondary to blunt TT is also found to prolong the hospital stay of the patients. In the light of them, we believe that if chest physiotherapy is to be performed, it should be performed carefully in patients with three or more RF in hospital conditions because of its possible risks.

Ethics Committee Approval: Approved by the local ethics committee.

Peer-review: Internally peer-reviewed.

Authorship Contributions: Concept: T.A.; Design: T.A., I.E.G.; Supervision: T.A., M.K.; Materials: T.A., I.E.G.; Data: T.A., I.E.G.; Analysis: T.A., M.K.; Literature search: I.E.G., T.A., M.K.; Writing: I.E.G., T.A.; Critical revision: T.A.

Conflict of Interest: None declared.

Financial Disclosure: The authors declared that this study has received no financial support.

\section{REFERENCES}

1. Karmy-Jones R, Jurkovich GJ. Blunt chest trauma. Curr Probl Surg 2004;41:211-380. [CrossRef]

2. Senn-Reeves JN, Staffileno BA. Long-term outcomes after blunt injury to the boney thorax: an integrative literature review. J Trauma Nurs 2013;20:56-66. [CrossRef]

3. Karmakar MK, Ho AM. Acute pain management of patients with multiple fractured ribs. J Trauma 2003;54:615-25. [CrossRef]

4. Hasbahçeci M, Ozpek A, Başak F, Calışkan M, Ener BK, Alimoğlu O. Factors affecting mortality in blunt thoracic trauma. Ulus Travma Acil Cerrahi Derg 2013;19:127-32. [CrossRef]

5. Söderlund T, Ikonen A, Pyhältö T, Handolin L. Factors associated with in-hospital outcomes in 594 consecutive patients suffering from severe blunt chest trauma. Scand J Surg 2015;104:115-20. [CrossRef]

6. Rodriguez RM, Hendey GW, Marek G, Dery RA, Bjoring A. A pilot study to derive clinical variables for selective chest radiography in blunt trauma patients. Ann Emerg Med 2006;47:415-8. [CrossRef]

7. Cakan A, Yuncu G, Olgaç G, Alar T, Sevinç S, Ors Kaya S, et al. Thoracic trauma: analysis of 987 cases. Ulus Travma Derg 2001;7:236-41.

8. http://www.tuik.gov.tr/PreHaberBultenleri.do;jsessionid=8FJDhyCWQJ1zgWYwrsL131DbCfbhxRc56SbHK4rTJR1MrBSTvSC1!116 535747 ?id $=27587$.

9. Plourde M, Émond M, Lavoie A, Guimont C, Le Sage N, Chauny JM, et al. Cohort study on the prevalence and risk factors of late pulmonary complications in adults following a closed minor chest trauma.[Article in French]. CJEM 2013;15:337-44.

10. Bulger EM. Inpatient management of traumatic rib fractures. Available from: http://www.uptodate.com/contents/inpatient-management-oftraumatic-rib-fractures.

11. Misthos P, Kakaris S, Sepsas E, Athanassiadi K, Skottis I. A prospective analysis of occult pneumothorax, delayed pneumothorax and delayed hemothorax after minor blunt thoracic trauma. Eur J Cardiothorac Surg 2004;25:859-64. [CrossRef]

12. Sharma OP, Hagler S, Oswanski MF. Prevalence of delayed hemothorax in blunt thoracic trauma. Am Surg 2005;71:481-6. [CrossRef]

13. Mowery NT, Gunter OL, Collier BR, Diaz JJ Jr, Haut E, Hildreth A, et al. Practice management guidelines for management of hemothorax and occult pneumothorax. J Trauma 2011;70:510-8. [CrossRef]

14. Wells BJ, Roberts DJ, Grondin S, Navsaria PH, Kirkpatrick AW, Dun- 
ham MB, et al. To drain or not to drain? Predictors of tube thoracostomy insertion and outcomes associated with drainage of traumatic hemothoraces. Injury 2015;46:1743-8. [CrossRef]

15. Simon BJ, Cushman J, Barraco R, Lane V, Luchette FA, Miglietta M, et al; EAST Practice Management Guidelines Work Group. Pain management guidelines for blunt thoracic trauma.J Trauma 2005;59:1256-67.

16. Ciesla ND. Chest physical therapy for patients in the intensive care unit. Phys Ther 1996;76:609-25. [CrossRef]

\section{ORIJINAL ÇALIŞMA - ÖZET}

\section{Künt toraks travması sonucu izole kot fraktürü gelişen hastalarda analjezik tedavi ve solunum fizyoterapisinin komplikasyonlara etkisi}

\section{Dr. Timuçin Alar, ${ }^{1}$ Dr. İsmail Ertuğrul Gedik, ${ }^{2}$ Dr. Murat Kara ${ }^{3}$}

\section{${ }^{1}$ Çanakkale Onsekiz Mart Üniversitesi Tıp Fakültesi, Göğüs Cerrahisi Anabilim Dalı, Çanakkale}

${ }^{2}$ Erzurum Bölge Eğitim ve Araştırma Hastanesi, Göğüs Cerrahisi Kliniği, Erzurum

${ }^{3}$ İstanbul Üniversitesi İstanbul Tıp Fakültesi, Göğüs Cerrahisi Anabilim Dalı, İstanbul

AMAÇ: Bu ileriye yönelik çalışmanın amacı künt toraks travmaları nedeniyle izole kot fraktürü gelişen olgularda solunum fizyoterapisi ve ağrı kontrolünün, olası komplikasyonlardan hemotoraks ve/veya pnömotoraks gelişim riski üzerine etkisinin araştırılmasıdır.

GEREÇ VE YÖNTEM: Bu ileriye yönelik çalısmaya Çanakkale Onsekiz Mart Üniversitesi Tıp Fakültesi Hastanesi Acil Servis ve Göğüs Cerrahisi Polikliniǧi'ne, künt toraks travması sonrası ilk 24 saat içinde başvuran ve izole kot fraktürü tespit edilen hastalar alındı. Kot fraktürü olan hastalardan ilk başvuru anında hemotoraks, pnömotoraks, yelken göğüs, atelektazi, pnömoni, akciğer kontüzyonu gibi ek yaralanması olmayan hastalar çalı̧maya dahil edildi. Hastalar, kapalı zarf usulü sadece analjezik tedavi verilecek hastalar (Grup A) ve analjezik tedavi ile birlikte solunum fizyoterapisi verilecek hastalar (Grup B) olarak iki ayrı gruba ayrıldı. Birinci ve ikinci kot fraktürü saptanan olgular ile üç veya daha fazla kot fraktürü saptanan ve ek organ yaralanması olmayan hastalar göğüs cerrahisi kliniğine, ek organ yaralanması olanlar ise ilgili kliniklere yatırılarak takibe alındı. Bu kriterlerin dışında kalan izole kot fraktürlü hastalar ise gerekli tedavileri düzenlenerek poliklinikten takip edildi. Olgular travmayı takip eden ilk hafta ve birinci ayın sonunda fizik muayene ve radyolojik incelemeler ile değerlendirildi.

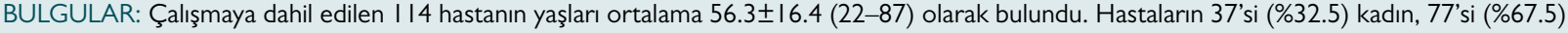
erkekti. A ve B gruplarına 57'şer hastadan oluştu. Hastaların en sık geçirdikleri travma \%3।.6 ile aynı seviyeden düşme idi. Hastaların kot fraktürü sayılarının ortalaması $2.6 \pm 0.7$ (I-I0), ortanca sayı I.5 olarak bulundu. Bu II4 hastanın 52'si (\%45.6) hastanede yatarak tedavi edildi. Çalışmaya alınan hastaların yatış süreleri incelendiğinde hastaların ortalama yatış süresi $4.0 \pm$ I.I idi. Tedavi ve takipleri sonucunda çalışmaya alınan I I 4 hastanın 28 'inde (\%24.6) kot fraktürü gelişen tarafta plevral efüzyon saptandı. Hastalarda plevral efüzyon gelişme durumunun gruplara göre dağılımı incelendiğinde B grubundaki hastalarda (\%43.9) A grubundaki hastalardan (\%5.3) istatistiksel olarak anlamlı şekilde daha fazla plevral efüzyon gelişimi izlendi $(p<0.000 \mathrm{I})$. Çalışmamızda takipler sonucunda $A$ grubundaki hiçbir hastaya müdahale gerekmezken, $B$ grubundaki dört hastaya hemotoraks tanısıyla tüp torakostomi uygulandı $(p<0.05)$.

TARTIŞMA: Çalışmamızda künt toraks travması sonucu izole üç ve daha fazla kot fraktürü gelişen hastalarda solunum fizyoterapisi uygulamalarının gecikmiş hemotoraks gelişme riskini önemli derecede artırdığı, minimal hemotoraksların $(<300 \mathrm{ml})$ uygun takip prosedürlerine uyulduğu takdirde spontan regrese olabileceği ve ek cerrahi müdahaleye gerek olmayabileceği tespit edilmiştir. Künt toraks travması sonucu üç ve daha fazla kot fraktürü olan hastalara eğer solunum fizyoterapisi uygulanması planlanıyorsa hastaların hastaneye yatıılarak takip ve tedavi edilmesi olası riskleri içeren ek komplikasyonlar gelişebilmesi açısından önerilebilir.

Anahtar sözcükler: Hemotoraks; kot fraktürü; künt toraks travması; solunum fizyoterapisi.

Ulus Travma Acil Cerrahi Derg 2020;26(4):531-537 doi: 10.14744/tjtes.2019.26356 